\title{
Analysis of interleukin (IL)-1ß IL-1 receptor antagonist, soluble IL-1 receptor type II and IL-1 accessory protein in HCV-associated lymphoproliferative disorders
}

\author{
MASSIMO LIBRA $^{1}$, KATIA MANGANO ${ }^{1}$, MASSIMILIANO ANZALDI ${ }^{1,2}$, CINZIA QUATTROCCHI $^{1}$, \\ MARCO DONIA $^{1}$, ROBERTO DI MARCO ${ }^{1,3}$, SANTO SIGNORELLI ${ }^{2}$, GUIDO SCALIA $^{4}$, ANNA L. ZIGNEGO ${ }^{5}$, \\ VALLI DE RE $^{6}$, MARIA C. MAZZARINO ${ }^{1}$ and FERDINANDO NICOLETTI ${ }^{1}$

\begin{abstract}
${ }^{1}$ Department of Biomedical Sciences, University of Catania; ${ }^{2}$ Department of Internal Medicine and Systemic Pathologies, Garibaldi Hospital, Universty of Catania; ${ }^{3}$ Department of Healthy Sciences, University of Molise; ${ }^{4}$ Department of Microbiological and Gynaecological Sciences, University of Catania; ${ }^{5}$ Department of Internal Medicine, University of Florence; ${ }^{6}$ Experimental Oncology 1, Centro di Riferimento Oncologico, IRCCS, National Cancer Institute, Aviano, Italy
\end{abstract}

Received November 22, 2005; Accepted December 29, 2005

\begin{abstract}
Hepatitis C virus (HCV) causes hepatitis, liver cirrhosis and hepatocellular carcinoma, and may also induce type II mixed cryoglobulinemia syndrome (MC), a disease characterized by clonal B-cell lymphoproliferations that can evolve into non-Hodgkin's lymphoma (NHL). Interleukin-1 (IL-1) is a cytokine that plays an important role in initiating the cascade of events of immunoinflammatory responses through costimulation of T lymphocytes, B-cell proliferation, induction of adhesion molecules and stimulation of the production of other inflammatory cytokines. The role of IL-1 in immunoinflammatory responses is highlighted by the presence of endogenous regulators (IL-1 receptor antagonist, soluble receptors type 1 and II, human IL-1 accessory protein) that, when secreted into the blood stream may serve as endogenous regulators of IL-1 action. The aim of this study was to evaluate whether abnormalities in the blood levels of IL-1ß IL-1 receptor antagonist, soluble IL-1 receptor type II and human IL-1 accessory protein in $\mathrm{HCV}^{+}$patients are associated with development of MC and/or NHL. Relative to healthy controls, we observed: i) an increase in the circulating levels of IL-1ß in $\mathrm{HCV}^{+}$patients simultaneously affected by NHL; ii) increased levels of IL-1 accessory protein in patients singly infected by $\mathrm{HCV}$; iii) increase of $\mathrm{IL}-1$ receptor antagonist in $\mathrm{HCV}^{+}$patients and in those affected also by NHL with or without MC; iv) a homogeneous increase of sIL-
\end{abstract}

Correspondence to: Dr Massimo Libra, Department of Biomedical Sciences, University of Catania, Via Androne 83, 95124 Catania, Italy E-mail: mlibra@unict.it

Key words: Interleukin-1, non-Hodgkin's lymphoma, mixed cryoglobulinemia syndrome
1R type II in all the subgroup of patients. These data indicate that an attempt to increased circulating levels of IL-1 inhibitors occurs at different extent in the course of $\mathrm{HCV}$ infection as well as in its progression to NHL and/or MC.

\section{Introduction}

Hepatitis $\mathrm{C}$ virus (HCV) is hepatotropic and causes hepatitis, liver cirrhosis and hepatocellular carcinoma (1). HCV may also induce autoimmune manifestations such as type II mixed cryoglobulinemia (MC). MC is characterized by cutaneous vasculitis, nephritis, peripheral neuropathy and clonal B-cell lymphoproliferations that can evolve into non-Hodgkin's lymphoma (NHL) $(2,3)$. A systematic review of 66 studies including over $6000 \mathrm{NHL}$ patients, showed a high prevalence of HCV positivity, especially in Italy (19.7\% of 2734 cases) and Japan (11.3\% of 771 cases) (4).

Although, there is much evidence implicating $\mathrm{HCV}$ in lymphoproliferation and lymphoma development, the pathogenetic mechanism underlying B-cell expansion and evolution to overt lymphoma is still unclear. Since HCV is lymphotropic its direct oncogenic role through B-cell infection and deregulation has been proposed but not proven. An additional pathogenetic hypothesis is that specific B-cell clones proliferate as a consequence of the chronic antigenic stimulation sustained by $\mathrm{HCV}$. Indeed, the immunoglobulin variable region gene sequence of tumour B-cells from $\mathrm{HCV}$-positive $\left(\mathrm{HCV}^{+}\right)$patients is the result of subsequent events of gene rearrangement, somatic mutation and antigenic selection (5).

An involvement of the immune system in the pathogenesis of $\mathrm{HCV}$-associated lymphoproliferative disorders is also likely to occur. Cytokines might be of particular relevance in this context as they play a central role in liver metabolism and in the immune response to viral agents (6) and increased intrahepatic levels of IL-2, IL- 6 and IL- 8 were demonstrated by RT-PCR in cirrhotic patients (7).

$\mathrm{IL}-1$, with the two isoforms IL- $1 \alpha$ and IL- $1 \beta$ is a cytokine belonging to the innate immune system that plays an important 
role in initiating the cascade of events of immunoinflammatory responses. By binding to specific high-affinity cell surface receptor type II in synergy with the interleukin receptor accessory protein (reviewed in ref. 8), IL-1 shows pleiotropic effects that include costimulation of $\mathrm{T}$ lymphocytes, B-cell proliferation, growth of fibroblasts, induction of adhesion molecules, stimulation of production of other cytokines and inflammatory mediators, growth-inhibitory and cytocidal effect for several cell lines (9). The importance of IL-1 in the physiology of the immune system is highlighted by the presence of multiple endogenous regulators such as the IL-1 receptor antagonist (ra), the interleukin receptor (IL-1R) type 1 and type II and the IL-1 accessory protein (Acp) that, when released into the bloodstream, may serve as naturally occurring inhibitors of IL-1 (10). Previous studies support the hypothesis that an imbalance between IL-1 and these naturally occurring inhibitors either in the general circulation or at the level of the organ targeted from the immunoinflammatory response may regulate the development and the natural course of chronic inflammatory diseases, such as inflammatory bowel diseases $(11)$, in rheumatoid arthritis $(10,12)$, multiple sclerosis $(13,14)$ and systemic lupus erythematosus $(15)$. Genetic polymorphism for the IL-1ra gene has also been reported for some autoimmune diseases (16-19).

An imbalance of IL-1ß and IL-1ra has also been found to occur in liver tissues from HCV related chronic hepatitis (20) and genetic polymorphism for both IL1ß and IL-1ra may increase the risk of $\mathrm{HCV}^{+}$patients to develop cirrhosis (21). However, it has not yet been studied whether a dysregulated balance between IL-1 and its naturally occurring inhibitors may also occur during the lymphoma development in the context of HCV infection. Hence, we studied the levels of IL$1 \beta$, soluble IL-1ra, IL-1 AcP and IL-1R type II in serum samples from $\mathrm{HCV}^{+}$patients who were also affected, either singly or in combination, by MC and B-cell NHL.

\section{Patients and methods}

Patients. Serum samples were collected from 114 subjects, $20 \mathrm{HCV}^{+}$patients with B-cell NHL (8 female and 12 male, mean age $61 \pm 9$ years), $15 \mathrm{HCV}^{+}$patients with both $\mathrm{MC}$ and B-cell NHL (7 female and 8 male, mean age $63 \pm 5$ years), 20 $\mathrm{HCV}^{+}$patients with $\mathrm{MC}$ (15 female and 5 male, mean age $60 \pm 8$ years), $14 \mathrm{HCV}^{+}$patients, (9 female and 5 male, mean age $52 \pm 9$ years) and 45 sex and age-matched healthy donors (25 females). The healthy controls did not suffer from infectious, allergic or autoimmune diseases nor had taken immunomodulatory drugs during the last 6 months before samples collection.

All patients were seronegative for human immunodeficiency virus (HIV). Informed consent was obtained from all patients, and peripheral blood collection was approved by Institutional Review Board. Fasting blood samples were obtained between 8 and 10 am to avoid possible circadian variations in the levels of the analyses. For all patients the sera were obtained at disease diagnosis and stored at $-80^{\circ} \mathrm{C}$ until analysis.

$\mathrm{HCV}$ infection was screened by searching for serum antibodies against $\mathrm{HCV}$ by the enzyme-linked immunosorbent assay (HCV 3.0; Ortho Diagnostic Systems, Raritan, NJ) and the recombinant-based immunoblot assay (Chiron RIBA; Ortho
Diagnostic Systems). Serum HCV RNA determination and genotype characterization were performed according to previously described procedures (22). All consecutive B-cell NHL cases were classified according to the "2001 World Health Organization (WHO) classification of tumors of Haematopoietic and Lymphoid Tissues' (23). MC was diagnosed according to already described criteria (24). In particular, these patients had detectable serum cryoglobulins for more than 6 months and at least 2 of the following symptoms and signs consistent with purpura, asthenia, arthralgia, renal involvement, and peripheral neuropathy were investigated, as well as serum cryoglobulins, $\mathrm{C} 3$ and $\mathrm{C} 4$, and rheumatoid factor levels.

\section{Cytokine analysis}

$I L-1 \beta$. Serum levels of IL-1ß were measured by solid-phase ELISA purchased by R\&D Systems (Minneapolis, MN). The assay was performed according to the manufacturer's instruction. The limit of the sensitivity of the assay was $2 \mathrm{pg} / \mathrm{ml}$.

Soluble IL-1ra. The soluble form of IL-1 receptor antagonist was measured by solid-phase ELISA purchased by R\&D (Minneapolis, MN). The assay was performed according to the manufacturer's instruction. The limit of sensitivity of the assay was $20 \mathrm{pg} / \mathrm{ml}$.

Soluble IL-1 receptor type II. The circulating levels of the soluble IL-1 receptor type II were measured by a solid-phase ELISA the reagents of which were kindly provided by AMGEN (Thousand Oaks, CA). The assay was performed according to the manufacturer's instructions. Briefly, Nunc maxisorb 96-well plates (Nunk, DK) were coated in $0.05 \mathrm{M}$ citrate buffer with $2 \mu \mathrm{g} / \mathrm{ml}$ of anti-hIL-1R II mAb at $4^{\circ} \mathrm{C}$. Standards or samples were incubated for $2 \mathrm{~h}$ at RT. After washing the plates 6 times with PBS/Tween $0.05 \%, 5 \mu \mathrm{g} / \mathrm{ml}$ of 1R II mAb Ab-peroxidase was incubated for $1 \mathrm{~h}$ at RT. As substrate $100 \mu 1$ of TMB (Sigma, St. Louis, MO) was used. The limit of the sensitivity of the assay was $<25 \mathrm{pg} / \mathrm{ml}$.

IL-1 AcP. The circulating levels of the soluble IL-1 AcP were measured by a solid-phase ELISA the reagents of which were kindly provided by AMGEN. The assay was performed according to the manufacturer's instructions. Briefly, Nunc maxisorb 96-well plates (Nunk, DK) were coated overnight in PBS with $1 \mu \mathrm{g} / \mathrm{ml}$ of anti-HuIL-1R AcP mAb (clone M355) at $4^{\circ} \mathrm{C}$ and then saturated for $1 \mathrm{~h}$ at RT with $\mathrm{PBS} / 0.005 \%$ Tween $/ 0.01 \%$ casein with $0.5 \mathrm{mg} / \mathrm{ml}$ purified rat IgG. Standards and samples were incubated for $1 \mathrm{~h}$ at RT. After washing the plates 6 times with PBS/Tween $0.05 \%$, biotinylated anti HuIL-1R AcP Ab (clone 60), diluted 1:1000, was incubated for $1 \mathrm{~h}$ at RT. Following six washings streptavidin peroxidase (Sigma, St. Louis, MO) was added for $30 \mathrm{~min}$ at RT. As substrate $100 \mu \mathrm{l}$ of TMB (Sigma, St. Louis, MO) was used. The limit of the sensitivity of the assay was $5 \mathrm{pg} / \mathrm{ml}$.

Statistical analysis. Data are presented as mean values \pm standard deviation (SD). Statistical analysis was performed by using one-way ANOVA. A p-value lower than 0.05 was considered significant. When blood levels of analyses were below the assay sensitivity, a theoretical value was assigned. 
Table I. Serum levels of IL-1ß, IL-1ra, IL-1R II, IL-1 and IL-1 AcP among HCV+ and HCV- individuals.

\begin{tabular}{lccccc}
\hline & $\begin{array}{c}\text { Healthy donors } \\
(\mathrm{n}=45) \\
\text { Mean } \pm \text { SD }\end{array}$ & $\begin{array}{c}\mathrm{HCV}^{+} \text {patients } \\
(\mathrm{n}=14)\end{array}$ & $\begin{array}{c}\mathrm{HCV}^{+} \mathrm{MC} \\
(\mathrm{n}=20) \\
\text { Mean } \pm \text { SD }\end{array}$ & $\begin{array}{c}\mathrm{HCV}^{+} \mathrm{NHL} \mathrm{with} \mathrm{MC}_{(\mathrm{n}=15)} \\
\text { Mean } \pm \text { SD }\end{array}$ & $\begin{array}{c}\mathrm{HCV}^{+} \mathrm{NHL}^{(\mathrm{n}=20)} \\
\mathrm{Mean} \pm \mathrm{SD}\end{array}$ \\
\hline IL-1B $(\mathrm{pg} / \mathrm{ml})$ & $5 \pm 3$ & $7 \pm 8$ & $4 \pm 2$ & $25 \pm 79$ & $70 \pm 204^{\mathrm{a}}$ \\
IL-1 $\mathrm{ra}(\mathrm{pg} / \mathrm{ml})$ & $113 \pm 114$ & $298 \pm 401^{\mathrm{a}}$ & $127 \pm 162$ & $200 \pm 176^{\mathrm{a}}$ & $393 \pm 753^{\mathrm{a}}$ \\
IL-1R II $(\mathrm{pg} / \mathrm{ml})$ & $2670 \pm 1235$ & $6025 \pm 1973^{\mathrm{a}}$ & $5512 \pm 1245^{\mathrm{a}}$ & $6536 \pm 4267^{\mathrm{a}}$ & $6658 \pm 2598^{\mathrm{a}}$ \\
IL-1 hAcP $(\mathrm{pg} / \mathrm{ml})$ & $1053 \pm 1223$ & $1892 \pm 887^{\mathrm{a}}$ & $1391 \pm 562$ & $1007 \pm 615$ & $1097 \pm 625$ \\
\hline
\end{tabular}

${ }^{\mathrm{a}} \mathrm{p}<0.05$; SD, standard deviation; MC, type II mixed cryoglobulinemia syndrome; NHL, non-Hodgkin's lymphoma.

\section{Results}

Table I indicates mean serum levels of IL-1ß, soluble (s)IL-1ra, IL-1AcP and sIL-1R type II analyzed in the different subsets of patients and the healthy donors. The mean serum level of each cytokine from each group of patients was compared with that from the healthy subjects. The mean serum level of IL-1ß was higher among the group of $\mathrm{HCV}^{+}$patients with B-cell NHL than healthy donors $(\mathrm{p}<0.03)$; however, only a trend was observed among the $\mathrm{HCV}^{+}$patients with both $\mathrm{B}$ cell NHL and MC syndrome $(\mathrm{p}<0.07)$. The mean serum level of sIL-1R type II was higher among all groups of patients than healthy donors $(p<0.0001)$. There were no significant differences in the magnitude of the increase among the different groups of patients. Relative to healthy controls, the mean serum level of IL-1ra was higher among $\mathrm{HCV}^{+}$patients, $\mathrm{HCV}^{+}$patients with $\mathrm{B}$-cell $\mathrm{NHL}$ and $\mathrm{HCV}^{+}$patients with both $\mathrm{B}$-cell NHL and MC syndrome, respectively $(\mathrm{p}<0.007$; $\mathrm{p}<0.01 ; \mathrm{p}<0.03)$. The mean serum level of IL-1 AcP was significantly higher only among $\mathrm{HCV}^{+}$patients compared to controls $(\mathrm{p}<0.02)$.

\section{Discussion}

Increasing evidence indicates that cytokines play an important role in liver metabolism and in the immune response to viral agents (6) and elevated intrahepatic levels of IL-2, IL-6 and IL-8 were demonstrated by reverse transcription-polymerase chain reaction (RT-PCR) in patients with cirrhosis (7). IL-1ß has been suggested to be involved in liver physiology and pathophysiology of the liver (25).

In the context of B-cell proliferation, it has been shown that HCV plays a pathogenic role in inducing B-NHL (2). The release of both cytokines and soluble mediators, HCVinduced, causes the chronic antigenic B-cell stimulation that has been proposed as an important pathogenic mechanism contributing to neoplastic transformation.

The lymphotropic action of HCV is consistent with studies in severe combined immunodeficiency (SCID) mice (26) showing the persistence and low-rate multiplication of $\mathrm{HCV}$ infection in human mononuclear cells.
Because B lymphocytes are responsive to the stimulatory action of IL-1 we have aimed to ascertain in this study whether imbalances in the circulating levels of IL-1 system including IL-1ß, sIL-1R type II, IL-1Acp and circulating IL-1ra could occur in $\mathrm{HCV}^{+}$patients with or without concurrent affection from NHL and/or MC and whether selective abnormalities could characterize any group of these patients.

The only selective results obtained from measuring these different analytes were the augmented serum levels of IL-1B observed in $\mathrm{HCV}^{+}$patients simultaneously affected by NHL and the increase of IL-1AcP that only occurred in the group of patients infected by HCV without evidence of lymphoproliferative disorders. No additional clear-cut data could be obtained from the analysis of our results as a homogeneous increase in the blood levels of sIL-1R type II observed in all the subgroup of patients and a significant increase of circulating IL-1ra in singly infected $\mathrm{HCV}^{+}$patients as well as in those simultaneously suffering from NHL with or without MC. Interestingly the increase in the circulating levels of IL-1ra, that has been reported in $\mathrm{HCV}^{+}$patients (27), was not observed in $\mathrm{HCV}^{+}$patients with $\mathrm{MC}$.

Taken together, the above data suggest that the overall elevation in at least one of the analytes from our sample series may reflect an ongoing immunoinflammatory response in which IL-1 is involved. In addition, the elevation of one or more endogenous IL-1 antagonists in our subset of patients indicates an attempt at mounting anti-inflammatory responses to, possibly, IL-1 driven immunoinflammatory events. That an upregulated production of IL- $1 \beta$ might play a role in lymphomagenesis in $\mathrm{HCV}^{+}$patients seems consistent with the augmented blood levels of this cytokine found in HCVassociated NHL patients. Although, the increased blood levels of IL-1ß in these patients could represent a secondary epiphenomenon devoid of pathogenic relevance, further studies are warranted to understand whether an abnormal synthesis of IL-1ß plays a role in development of NHL during $\mathrm{HCV}$ infection. Proving a pathogenic role of IL-1 in lymphomagenesis in the context of HCV infection could open novel therapeutic approaches for prevention of NHL that are aimed at negating the action of endogenous IL-1 with specific inhibitors such as the IL-1ra that has already shown clinical efficacy in patients with rheumatoid arthritis (28). 


\section{Acknowledgments}

The authors thank Dr. John Sims (AMGEN Seattle, WA, USA) for providing the reagents for measurement of circulating IL-1 accessory protein and soluble IL-1 type II receptor. This work was partially supported by COFIN MIUR, Italy; by Italian Association for Cancer Research (AIRC).

\section{References}

1. Lauer GM and Walker BD: Hepatitis C virus infection. N Engl J Med 345: 41-52, 2001

2. Silvestri F, Pipan C, Barillari G, et al: Prevalence of hepatitis C virus infection in patients with lymphoproliferative disorders. Blood 87: 4296-4301, 1996.

3. Quinn ER, Chan $\mathrm{CH}$, Hadlock KG, Foung SK, Flint $\mathrm{M}$ and Levy S: The B-cell receptor of a hepatitis C virus (HCV)associated non-Hodgkin's lymphoma binds the viral E2 envelope protein, implicating $\mathrm{HCV}$ in lymphomagenesis. Blood 98: 3745-3749, 2001.

4. Negri E, Little D, Boiocchi M, La Vecchia C and Franceschi S: B-cell non-Hodgkin's lymphoma and hepatitis $\mathrm{C}$ virus infection: a systematic. Int J Cancer 111: 1-8, 2004.

5. Libra M, Gasparotto D, Gloghini A, Navolanic PM, de Re V and Carbone A: Hepatitis $\mathrm{C}$ virus (HCV) infection and lymphoproliferative disorders. Front Biosci 10: 2460-2471, 2005.

6. Andus T, Bauer J and Gerok W: Effects of cytokines on the liver. Hepatology 13: 364-375, 1991.

7. Napoli J, Bishop GA and McCaughan GW: Increased intrahepatic messenger RNA expression of interleukins 2,6 , and 8 in human cirrhosis. Gastroenterology 107: 789-798, 1994.

8. Sims JE and Smith DE: Regulation of interleukin-1 activity is enhanced by cooperation between the interleukin- 1 receptor type II and interleukin-1 receptor accessory protein. Eur Cytokine Netw 14: 77-81, 2003.

9. Onozaki K, Matsushima K, Aggarwal BB and Oppenheim JJ: Human interleukin-1 is a cytocidal factor for several tumor cell lines. J Immunol 135: 3962-3968, 1985.

10. Dinarello CA: Therapeutic strategies to reduce IL-1 activity in treating local and systemic inflammation. Curr Opin Pharmacol 4: 378-385, 2004

11. Cominelli $\mathrm{F}$ and Pizarro TT: Interleukin-1 and interleukin-1 receptor antagonist in inflammatory bowel disease. Aliment Pharmacol Ther 2: 49-53, 1996.

12. Arend WP: Cytokine imbalance in the pathogenesis of rheumatoid arthritis: the role of interleukin-1 receptor antagonist. Semin Arthritis Rheum 30: 1-6, 2001.

13. Nicoletti F, Patti F, diMarco R, Zaccone P, Nicoletti A, Meroni P and Reggio A: Circulating serum levels of IL-1ra in patients with relapsing remitting multiple sclerosis are normal during remission phases but significantly increased either during exacerbations or in response to IFN-beta treatment. Cytokine 8: 395-400, 1996.
14. De Jong BA, Huizinga TW, Bollen EL, et al: Production of IL-1beta and IL-1Ra as risk factors for susceptibility and progression of relapse-onset multiple sclerosis. J Neuroimmunol 126: $172-179,2002$

15. Chang DM: Interleukin-1 and interleukin-1 receptor antagonist in systemic lupus erythematosus. Immunol Invest 26: 649-659, 1997.

16. Mandrup-Poulsen T, Pociot F, Molvig J, et al: Monokine antagonism is reduced in patients with IDDM. Diabetes 43: 1242-1247, 1994.

17. Crusius JB, Pena AS, van Oosten BW, et al: Interleukin-1 receptor antagonist gene polymorphism and multiple sclerosis. Lancet 346: 979, 1995.

18. Perrier S, Coussediere C, Dubost JJ, Albuisson E and Sauvezie B: IL-1 receptor antagonist (IL-1RA) gene polymorphism in Sjogren's syndrome and rheumatoid arthritis. Clin Immunol Immunopathol 87: 309-313, 1998.

19. Carter MJ, Jones S, Camp NJ, et al: Functional correlates of the interleukin-1 receptor antagonist gene polymorphism in the colonic mucosa in ulcerative colitis. Genes Immun 5: 8-15, 2004.

20. Gramantieri L, Casali A, Trere D, et al: Imbalance of IL-1 beta and IL-1 receptor antagonist mRNA in liver tissue from hepatitis $\mathrm{C}$ virus (HCV)-related chronic hepatitis. Clin Exp Immunol 115: 515-520, 1999.

21. Bahr MJ, el Menuawy M, Boeker KH, Musholt PB, Manns MP and Lichtinghagen R: Cytokine gene polymorphisms and the susceptibility to liver cirrhosis in patients with chronic hepatitis C. Liver Int 23: 420-425, 2003.

22. Libra M, Gloghini A, de Re V, et al: Aggressive forms of nonHodgkin's lymphoma in two patients bearing co-infection of Epstein-Barr and hepatitis C viruses. Int J Oncol 26: 945-950, 2005.

23. Harris NL, Jaffe ES, Diebold J, et al: The World Health Organization classification of neoplastic diseases of the haematopoietic and lymphoid tissues: report of the Clinical Advisory Committee Meeting, Airlie House, Virginia, November 1997. Histopathology 37: 282-283, 2000 .

24. Zignego AL, Ferri C, Giannini C, et al: Hepatitis C virus genotype analysis in patients with type II mixed cryoglobulinemia. Ann Intern Med 124: 31-34, 1996

25. Peters M: Actions of cytokines on the immune response and viral interactions: an overview. Hepatology 23: 909-916, 1996.

26. Bronowicki JP, Loriot MA, Thiers V, et al: Hepatitis C virus persistence in human haematopoietic cells injected into SCID mice. Hepatology 28: 211-218, 1998.

27. Cotler SJ, Craft T, Ferris M, et al: Induction of IL-1Ra in resistant and responsive hepatitis $\mathrm{C}$ patients following treatment with IFN-con1. J Interferon Cytokine Res 22: 549-554, 2002.

28. Furst DE: Anakinra: review of recombinant human interleukin-1 receptor antagonist in the treatment of rheumatoid arthritis. Clin Ther 26: 1960-1975, 2004 